\title{
Swami Vivekananda - The Teacher
}

\author{
Sudhish Chandra Banerjee* \\ 2 Diamond Park, Kohinoor Apt. Flat-10, PO-JOKA, Kolkata-700104, India
}

*Corresponding Author: Sudhish Chandra Banerjee, 2 Diamond Park, Kohinoor Apt. Flat-10, POJOKA, Kolkata-700104, India

\begin{abstract}
Swami Vivekananda (Swamiji) was ordained to be the world teacher by his Guru himself. Swamiji taught the world in awakening the innate divinity through Yoga, attaining super consciousness mind-state with awareness of the infinite world that exist with cosmic mind, beyond our limited sensory-world.. Swamiji preached for man-making education awakening innate divinity.
\end{abstract}

Some of his messages imparted as the world teacher are:

- All knowledge is within us, with awakening of the self it gets manifested.

- Western education, enabling one to be self-supporting, should be coupled with Eastern values Brahmacharya as the guiding motto, with Shraddha and faith in one's self.

- Nation building demands all inclusive education reaching the masses.

- Women education is stressed upon with Sri Ma Sarada Devi's ideal as the pivotal point; imparting self-supporting and character building education, having no control of men in their management.

- We should do good to the world, apparently to help the world, but really to make us pure and perfect.

- Swamiji was beloved to all, being an emblem of personified Love- much more than his dazzling personality and wisdom of a sage.

He was the prophet of a new and future order of development.

Keywords: Anne Masefield Sullivan, Multi-verse, Prana, Personal magnetism, Divinity, Education, Nivedita, Sri Ma Sarada Devi, Women-education, Sadananda

\section{INTRODUCTION}

Helen Keller was born 20 years after Swami Vivekananda's birth in 1863. She was locked in isolation when she became deaf and blind at a very tender age due to Scarlett fever. The only sense organ that remained active to the deaf, mute and blind girl was the sensation of touch. Miss Anne Masefield Sullivan (herself blind) was a gifted teacher and by her unique method of teaching by the means of touch opened up Helen's sense world of 'word linked with thought' making her a celebrity American author, political activist and lecturer overcoming her serious limitations due to nonfunctioning of the major sensory organs. ${ }^{1}$ Thus Helen Keller could perform as well, as anybody with functioning sense organs and could appreciate the songs of Rabindra Nath Tagore, just by touching his lips, when Tagore sang for her².

Helen Keller was conscious of her limitations in accessing the world of the senses but we are absolutely ignorant of the existence of the much bigger chunk of the world that do exist beyond the sensory world. Our level of consciousness is bound by the fetters of viewing everything through the perception of the five sense organs. Swami Vivekananda (Swamiji) made us aware of the limitations of the sensory world, defining the world to be of 'Infinite existence*. He explained as to how through Yoga, by the appropriate nurturing of the mind, we can access the boundless unknown realm of the world through attaining a state of the mind which is much above our level of consciousness. Without Swamiji's assertions we would have been locked up in isolation to the limits of the sensory organs, ignorant of the existence of our own higher self. Thus similar to Sullivan who showed Helen Keller the path to feel light and sound, Swamiji, showed us the path in which we can go beyond the boundary of the five sense organs and thus may be applauded as a great world teacher--the teacher of the teachers. 
[*As if echoing Swamiji, modern Physicists of $21^{\text {st }}$ century speak of the existence of a mysterious force \& unknown staff termed dark energy and dark matter which consist $96 \%$ of the universe, making our known universe -including our solar system with the stars/ nebulae /black holes etc- to be limited to only $4 \%$. The existence of this $96 \%$ unknown mysterious staff has been conjectured, to explain the accelerated expansion of the universe $\mathrm{s}^{3}$ ]

Explaining about our common place view of the world, Swamiji writes in a poetic language, "The whole universe to us is a writing of the Infinite in the language of the finite",4. Elucidating it he said, "A little of the Infinite projected into the consciousness ....we call our world. .... there is an Infinite beyond... and religion has to deal with both - with the little lump we call world; and with infinite beyond". 5 Explaining the scheme of the universe Swamiji clarified, "It is a circle within a circle, universe within universe ${ }^{\mathrm{a}}$. We have five senses and we represent Prana ${ }^{\mathrm{b}}$ in a certain state of vibration. ... ...Our range of vision is (in) only one plane of vibration of this Prana. ... The universe .. (consists) of layer after layer of varying degrees of vibration ${ }^{c}$, ...........we can by Yoga (proper nurturing of the mind) bring ourselves to the state of vibration of another plane and thus enable ourselves to see what is going on there", 6

[a) As if echoing Swamiji, many of the $21^{\text {st }}$ century Physicists are introducing the concept of the existence multiverse instead of the term uni-verse that we speak of. ${ }^{7}$

b) Prana is a term used in the scriptures \& in Vedanta; a simplified version of which can be explained as the 'generalised manifestation of force (or rather energy of all sorts including life force);. ..... "It is the Prana that is manifesting action of the body and nerve currents, as thought force. From thought down to the lowest force everything is, manifestation of Prana', 8 "....the physical manifestation of the Prana by physical means is called physical science, and that part which tries to control the manifestation of Prana as mental force by mental means is called Raj-Yoga ${ }^{9}$. Prana is the infinite omnipresent manifestation of power of this universe ${ }^{10}$.

c) Like the $21^{\text {st }}$ century physicists, explaining the scheme of the universe from the String Theory or, Theory of Everything, which is vibratory mode of things; Swamiji could visualize that "The whole universe is composed of subtle vibrations, $\left.{ }^{11,}\right]$

Deducing the methodology on 'culture of the mind' in accessing the world beyond our sense world, Swamiji speaks of the extraordinary power of the mind which can be manifest if properly cultivated. Citing a few examples on the extraordinary feats that our mind is capable of ${ }^{12}$, Swamiji, as a great world teacher, spelt out the science and methodology of cultivating such immense power of the mind (Practicing Yoga, etc). He assures that each one of us can grow such immense power of the mind and become great. The degree of excelling depends on the individual efforts with innate astuteness on mind control ${ }^{13}$.

Swamiji further explains saying, "..there is no such realities as physical world, a mental world and a spiritual world. Whatever is, is one. .....it is a tapering existence; the thickest part is here, it tapers and becomes finer and finer. The finest is what we call spirit; the grossest the body. ..... The universe of ours ......is the gross external thickness, and it tapers into something finer and finer until it becomes God",13.

Explaining the theory on 'art of mind control' Swamiji adds, since all power lies with the finer part of the gross body (like the tiny thread like nerves bringing power to the swelling muscles), if we get 'at the root of the thought (finer part of it)' before it appears as a full blown thought ultimately culminating to action, then it can be controlled. That is why purity and morality have always been the object of religion; since it is only a pure moral man who can achieve such control over his own mind. Also, by knowing the secret on evoking of the ripples of thought process one can attain the power to control every mind" ${ }^{14}$; since our mind is continuity with the universal mind and can convey our thoughts directly with one another irrespective of the location ${ }^{15}$. Speaking more explicitly Swamiji says, "our bodies, our virtues ...our spirituality, all these are continuously influencing others....conversely ...we are (also) being influenced". ${ }^{15}$ " Swamiji terms this as personality of a person, or, personal magnetism; which may be considered to be a very important trait for a successful teacher.

Testimony of such personal magnetism have been cited by the famous sculptor Malvina Hoffman in her memoirs about the spell that Swamiji cast on her when she met him whilst she was a child. She 
writes many decades later, "He made an imperishable impression upon me. He seemed to personify the mystery and religious 'aloofness' of all true teachers of Brahma....... recalled with emotion ....this holy man ..Revealed to me more of the true spirit of India, without even uttering a word, than I had ever sensed in the many lectures .on India.. ..which I attended since" ${ }^{16}$.. Same is the story on the Chicago address of Swamiji. Mrs S.K. Blodgett wrote about it saying "I was at the Parliament of religion in Chicago, in 1893. .... When that young man (Swamiji) got up and said, 'Sisters and brothers of America', seven thousand people (of the Columbus hall) rose to their feet as a tribute to something they knew not what" ${ }^{\prime 17}$. There is no explanation other than personal magnetism, to explain the deafening applause that followed for two minutes, from use of those simple 5 words of Swamiji, addressing as 'sisters and brothers of America.'

Coming back to the context on Swamiji's assertions about control and power of the mind, it has been stated that, "The whole of the universe is built upon the same plan ...... So just as I have a mind, there is a cosmic mind. As in the individual, so in the universal ${ }^{18}$," He says further, "There is no limit to the power of human mind. The more concentrated it is, the more power is brought to bear on one point; that is the secret......The goal of all Raj Yoga's teaching is how to concentrate the mind, then how to discover the innermost recesses of our own mind. The Yogi teaches that the mind itself has a higher state of existence, beyond reason, a super conscious state, and when the mind gets into that higher state, then this knowledge, beyond reason comes to man" ${ }^{19}$. All the different steps in Yoga are intended to bring us scientifically to that super--conscious state.

While speaking of Raj-Yoga, Swamiji said, "All knowledge is within the mind......Every individual can become divine. That is only possible when every individual has absolute mastery over his own thoughts....The thoughts of the senses should be my servants, not my masters. ...Education is not filling the mind with lots of fact. Perfecting the instrument (of mind) and getting complete mastery over my own mind, is the ideal of education. If I want to concentrate my mind upon a point, it goes there, and the moment, I call it, it is free. " ${ }^{20}$. It is the power of concentration, the power of attachment to a certain object as well as detachment that we must develop. In fact, attainment of such power of the mind is what Swamiji calls upon as awakening of the inner divinity of man, which has been stressed upon to be the purpose of education.

It is pertinent to include elucidation of the following topics for a better understanding of Swamiji as the world teacher.

- The inclusive education policy and its importance as spelt out by Swamiji.

- The importance of women's education and their role in nation building, particularly in the context of India.

- Aspects on divinity which is innate in all human beings, as advocated by Swamiji and its various connotations..

- Uniqueness and the originality of Swamiji's teachings.

A brief resume of the above four topics, (amongst many other aspects on human life and society that Swamiji delved upon), are discussed below.

\section{EDUCATION AND ITS IMPORTANCE AS SPELT OUT BY SWAMIJI}

Swamiji laid great stress on education of the masses in nation-building, saying 'strength of a nation comes through education' ${ }^{21}$. He pressed for the right type of education in character building which also instills self-confidence, both in the individual level as well as for the nation at large, when spread across the masses. This was expressed in his letter to Sarala Ghosal to whom he writes-- "A nation is advanced in proportion as the education and intelligence is spread among the masses. The chief cause of India's ruin has been monopolising the whole of education .....among a handful of men. If we are to rise again we shall have to ....spread education among the masses ....Through education comes faith in one's own self, and through faith in one's Self the inherent Brahman wakes up...Infinite power is latent in this Jivatma (individual soul); from the ant to the perfect man there is the same atman in all, the difference being only in manifestation. ...We shall have to call forth that power (through right type of education) by going from door to door (amongst the masses) ${ }^{, 22}$. This thought was unique as all of ancient Indian education system relied on secrecy and spread of knowledge within a limited coterie of select pupils imparted by a handful of masters. 
He was however well aware of the limitations in reaching education to the poor and downtrodden for their unavoidable compulsions due to--- economic distress and said, "Suppose you start schools all over India for the poor, still you cannot educate them. The boy of four years would better go to plough or to work, than to your school......If the ploughman's boy cannot come to education, why not meet him at the plough, at the factory, just wherever he is" ${ }^{23}$. India has one of the highest rate of school drop-outs and the literacy rate is still $74.04 \%$ after 7 decades of independence ${ }^{24}$.

Swamiji's views on "if the ploughman's boy cannot come to education, why not meet him at the plough, at the factory, just wherever he is $"{ }^{25}$; is perhaps the solution to involve the masses in education. His vision perhaps also talked about tele-education/web-education at an age when conventional schooling was the norm. He has expressed deep concerns about uplifting the poor and downtrodden in various writings and letters. On the $19^{\text {th }}$ March, 1894 he writes from USA to his fellow monk Swami Ramakrishnananda--- " My brother, .in view of.... the poverty and ignorance (of the countrymen), I had no sleep. That these poor people are leading the life of brutes is simply due to ignorance.......Suppose some disinterested Sannyasins, bent on doing good to others, go from village to village, disseminating education ....through oral teaching, and by maps camera, globes and all such accessories can't that bring forth good in time?... The poor are too poor to come to school....We as a nation have lost our individuality, and that is the cause of all mischief in India. We have to give back to the nation its lost individuality and raise the masses.....To effect this, the first thing we need are men, and the next is funds." ${ }^{25 a}$. It may be relevant to add in this context Swamiji himself wanted to raise funds for such purpose, as could be earned from his lecture tours at USA ${ }^{26}$; but it got fizzled out being defrauded by the Slayton Lyceum Lecture Bureau of Chicago*, who were entrusted to arrange such US lecture tours of Swamiji ${ }^{26 a}$.

[* Later the American press themselves admitting such defrauding of the lecture bureau commented, "We have robbed him (Swamiji) of the funds to which he was entitled to..... No wonder he feels bitter towards Americans as money-loving country when he has realized hardly nothing from his lectures for the grand object he had in view -the establishment of ... educational institutes in India- while the unscrupulous managers have reaped them all. Kananda (meaning Vivekananda) knows not the value of money. He was an easy mark for the speculating managers $^{27}$ ]

The next pertinent question that is considered important is the type of education that Swamiji advocated for uplifting the nation. Swamiji rightly said, "All the wealth of the world cannot help one little village, if people are not taught to help themselves. Our work should be mainly educational, both moral and intellectual",28. Elaborating this approach Swamiji said to his disciple Sarat Chandra Chakraborty, "You consider a man as educated if he can pass some examination and deliver good lecture. The education which does not help the common mass of people to equip themselves for the struggle for life, which does not bring out strength of character, a spirit of philanthropy, and the courage of a lion- is it worth the name? ....Real education is that which enables one to stand in one's own legs..." 29 . Speaking it more explicitly on imparting this 'self supporting system of education' to ensure material prosperity at the first stage, Swamiji commented, "With the help of Western science set yourself to dig the earth and produce food staff ....by discovering new avenues to production, ..so as to be able to produce food and clothing ....for want of food and clothing ...the country has come to ruin .... teach the people first the means of procuring their food and clothing, and then you will find time to read to them the scriptures. If their material wants are not removed by the rousing of intense activity, none will listen to words of spirituality. ...teach them first of all to make provision of food and then teach them religion" ${ }^{, 30}$. Unlike other spiritual masters who talk of scriptures and philosophy only-- Swamiji went to the core of the problem. He advocates education to be spread first, in order to achieve material prosperity and then to talk of scriptures. In many of the press meets at US Swamiji expressed the same opinion of taking the help of western science* for making the Indian masses self supporting, who remained famine stricken most of the times under the British rule. On the point of sending the missionaries in India for spreading the message of Christ, Swamiji's response was loud and clear and used to say "Send the missionaries in India to teach them how to earn a better piece of bread and not to teach them metaphysical non-sense",31. Swamiji's heart bled to see the sad plight of Indians under British rule with no practical education of how to fend themselves and said, "It is a practical want of intellectual education about life on this earth they (Indians ) suffer from. ....they must have a better piece of bread and better piece of rag on their bodies. The great question is: How to get that better bread and better rag for these sunken millions." ${ }^{, 32}$ 
[*As if prophesying to take the help of western science to grow more food etc, Indian Scientists (IARI) did develop new techniques for more food production utilizing western science, making green revolution a success, whereby India emerged from food importing country to the food exporting country, quite a number of decades afterwards, fulfilling Swamiji's aspiration. ${ }^{33}$ ].

Swamiji's had a very high opinion about the potentiality of the masses and gave his message loud and clear to the educated class, saying "The masses in our country are like sleeping Leviathan. The education imparted by the present education system reaches one or two percent of the masses only......Instruct them (the masses) in simple words about the necessities of life, and in trade, commerce, agriculture, etc. If you cannot do this, then fie upon your education and culture..." ${ }^{34}$. He speaks of this at a time when the usual mode of imparting college education was a combination of esoteric languages, law, logic, science, metaphysics and literature. Concepts of imparting knowledge of technical skills and agricultural practices was never part of the education system in Swamiji's time. The visionary Swami speaks of this 130 years back.

His wanted to keep the monks of the newly set up Ramakrishna Mission updated in the advancement of modern science and wrote to his disciple Swami Sudhananda in 1897 stating "I made before as to getting a set of Chemical and Physical apparatus and starting classes in elementary and experimental Chemistry and Physics, especially Physiology.... What about buying all scientific books that have been translated in Bengali(for preserving in his newly set up Ramakrishna Mission's Library)?, ${ }^{35}$ It is amazing to note that this ochre clothed monk talked not only about deep Vedantic philosophy but also about science and its importance to everybody including the monks practicing renunciation.

Swamiji also appreciated the importance on western system of education imparting utilitarian/ science lessons to make one self-supporting, but at the same time he was apprehensive of loss of old Indian values like, politeness and Shradha ${ }^{36}$. He therefore wanted a synthesis of both as the ideal scheme. He was of the view that all knowledge is within us. It needs awakening of the self to get it manifested. Elaborating such a comprehensive system of education, in reply to the queries of his childhood friend Priya Nath Sinha, Swamiji opined----, "What we want is Western science coupled with Vedanta; Brahmacharya as the guiding motto, and also Shraddha and faith in one's self.....within man is all knowledge - it requires only an awakening and that much is the work of a teacher. ....they (students) may learn to apply their own intellect to the proper use of hands, legs, ears, eyes, etc. and finally everything will become easy. But the root is religion. ... What we need is to study ...different branches of the knowledge ....and with it the English language and Western science; we need technical education (also) ..... that may develop industries" ${ }^{, 37}$.

At the same time, Swamiji advocated for wider spread of Sanskrit education as well, which he opined to be identified with the culture of India; also saying 'Sanskrit and prestige go together' ${ }^{38}$. Sister Nivedita rightly wrote, "How to nationalise the modern and modernise the old, so as to make the two one, was a puzzle that occupied much of his (Swamiji's) time and thought. He rightly saw that only when it had been pieced together, could national education be in a fair way to begin",39.

Stressing upon education in building up moral character besides being self-supporting, Swamiji realised the importance of the teachers who could be iconic as inspirational figures to the students. He therefore wanted self-sacrificing idealists (say monks) to take the role of a teacher, who renunciate everything for doing good to many. Spelling out such ideal format of education, Swamiji continued saying "...every boy should be trained to practice absolute Brahmacharya and then only faith and Shraddha will come. ...India had good prospects so long as Tyagis (men of renunciation) use to impart knowledge ${ }^{, 40}$. Reiterating it further Swamiji explained that the sole aim of the system of education should be man-making, and not just cramming, as is encouraged in the prevalent education system (during Swamiji's time as also at present). He held that mind of the man is an infinite reservoir of knowledge, and all knowledge, present past and future, is within man, manifested or, non-manifested and the object of every education system should be to help the mind manifest $\mathrm{it}^{41}$.

It may be pertinent to add here that though India in the past had a rich heritage and culture of scholastics spread equally amongst both men and women*; but in nineteenth century (as also covering a long period previous to that), women's education were not only neglected but thoroughly discouraged, for various historical maladies with dark ages that engulfed India since. 
[*There are two distinctly separate words in Sanskrit, to mean the Acharya's (who explains \& teaches Vedas) wife (feminine gender) and a woman Acharya, who herself teaches Vedas; proving women teachers were then as common as men. The former in Sanskrit is termed 'Acharyani' whereas the latter as 'Acharyaa']

Swamiji very strongly advocated for spread of women education to the highest level. He stressed "If the women are raised through the spread of education, then their children will by their noble actions glorify the name of the country-then will culture, knowledge, power and devotion awaken the land",42. In fact, Swamiji's views were far more revolutionary than the then social reformers who also advocated for spread of women's education. Swamiji opined, "Women will work out their own destinies -much better, too than men ever do for them. All the mischief to women has come because men undertook to shape the destiny of women",43. This requires a more detailed introspection specially Swamiji's notion on women's role in nation building and is discussed below.

\section{WOMEN'S ROLE IN NATION BUILDING AS PER SWAMIJI'S VIEWPOINT}

Swamiji's thoughts on women's education has somewhat to do with his upbringing and Western education but it has a lot more to do with his association with the divine Mother-Sri Ma Sarada Devi. She herself was uneducated but emphasized women's education and their empowerment. It may be worth mentioning that Sri Sri Sarada Devi sent Sarala Devi (first president of Sarada Math) for nursing training and this was at a time when the Bengali society looked down upon nurses and the job was considered to be quite menial. Inspiration from Sri Sri Sarada Devi shaped a lot of Swamiji's thoughts on empowerment of women and the need for their upliftment. Emphasizing women's education, Swamiji said to his disciple Sarat Chandra Chakraborty quoting the scriptures, "If you do not raise the women, who are the living embodiment of Divine Mother, don't think you have any other way to rise..........In an assembly of thousand Brahmanas who were all erudite in Vedas, Gargi boldly challenged Yanjnabalkya ... Since such ideal women were entitled to spiritual knowledge, why shall not the women have the same privilege now. ... That country and that nation which do not respect women have never become great, nor will ever be in future. The principal reason why your race has so much deteriorated is that you have no respect for these living images of Shakti..... Manu says 'where women are respected, there the Gods are delighted; and where they are not, there all work and efforts come to naught'....There is no hope for rise for that family or country where there is no estimation of women, where they live in sadness" $" 44$.

Child marriage of girls and thus depriving them of their childhood -- denying them a right to education, livelihood, free thought and pushing them to domesticity only still remains prevalent in India. In many of his writings Swamiji expressed his deep hatred for such child marriage depriving the womenfolk from educational opportunities; and he even considered it a sin perpetrated, weakening the race ${ }^{46}$. He writes to his disciple Alasingha--- " A railway porter here (in America) is better educated than most of your young men, and most of your princes. Every American woman has far better education than can be conceived by the majority of the Hindu woman-why cannot we have the same education? We must." ${ }^{47}$. In fact, he held very high opinion of the then American women, of whom he said, "Nowhere in the world are women like those of this country. How pure, independent, self-relying, and kind-hearted! It is the women who are the life and soul of this country. All learning and culture are centered in them. ... I am struck dumb and wonder at seeing the women of America",48. It is important to note that he celebrates and holds in high esteem women's education resulting in their independence, equality and self reliance and this is much prior to 1920 when the 19th Amendment to the U.S. Constitution granted American women the right to vote.

At the same time religion was considered to be the innermost core in his concept on an ideal education system for women (as also for men). ${ }^{49}$. Reiterating it further Swamiji said, "The idea of perfect womanhood is perfect independence.. ...The Hindu women are very spiritual and very religious,.... If we can preserve these beautiful characteristics and at the same time develop intellects of our women, the Hindu women of the future will be the ideal woman of the world, ${ }^{, 50}$.

Stressing upon spirituality as the main plank of education, Swamiji said, "Mere book learning won't do. We want that education by which character is formed, .....strength of mind is increased, ...the intellect is expanded, and by which some can stand on his own feet ${ }^{51}$. It would seem to be a revolutionary idea where Swamiji wanted to include the women to learn self- defense as well in the curricula of their educational system ${ }^{51}$. 
It was in Sister Nivedita (Miss Margaret Noble of Wimbledon, UK) in whom Swamiji could find all such ideals of character, strength of mind, intellect, spirituality, all blended together. Thus when Nivedita expressed her desire to work for India, Swamiji wrote a very emotive letter, saying, "Let me tell you frankly that I am now convinced that you have a great future in the work for India. What was wanted was not a man, but a woman - a real lioness, to work for Indians, women especially. India cannot yet produce great women, she must borrow them from other nations. Your education, sincerity, purity, immense love, determination and above all, the Celtic blood make you just the woman wanted." ${ }^{52}$. Of course in the same letter Swamiji laid bare the harsh and pitiable condition she would have to face if she chooses to work for India. But Sister Nivedita was not dissuaded and devoted her life not only for the advancement of women's education but struck a chord in every sphere in uplifting for India's all out welfare. She also took an active part with an important role in India's freedom struggle. Later Sister Christine, (Christina Greenstidel, of Detroit, America) another spiritual daughter of Swamii, joined Sister Nivedita's efforts in education of women which she kept on continuing even after the death of Sister Nivedita in $1911^{53}$.

The weightage Swamiji used to give on women's education can be gauged from Sister Nivedita's writings, as she writes, "The Swami felt that there was no task before India which could compare in importance with that of women's education. His own life had had two definite personal purposes, of which one had been the establishment of a home for the Order of Ramakrishna, while the other was the initiation of some endeavour towards the education of women. With five hundred men, he would say, the conquest of India might take fifty years: with as many women, not more than a few weeks, ${ }^{54}$ . Swamiji laid far more stress on women's role in nation building far more than men is, because of the endearing motherly qualities innate in women, enabling them to relate to all better and make all as their own.

Speaking about the great possibility that awaited to make India great with Sree Ma Sarada Devi* taking a pivotal role, Swamiji wrote a very significant letter from USA in 1894 to his fellow monk Swami Sivananda. He wrote, "Without Shakti (Power) there is no regeneration for the world. Why is it that our country is the weaker and the most backward of all countries- because Shakti is held in dishonour here. Mother (Sri Ma Sarada Devi) has been born to revive that wonderful Shakti in India and making her the nucleus; once more will Gargi and Maitreeyis be born in this world....... What do I find in America and Europe? - the worship of Shakti, the worship of power. Yet they worship Her ignorantly through sense gratification. Imagine then what a lot good they will achieve who will worship Her with all purity, in a Satvika spirit, looking upon Her as their mother!',55.

[*To Swamiji she was the emblem of Shakti, the living Goddess Durga; and to Nivedita, 'Her life is one long stillness of prayer. Her whole experience is of theocratic civilization. Yet she rises to the height of every situation",56.]

In the same letter Swamiji expressing his deep devotion to Sri Ma (Sarada Devi) frankly admitted that he is rather bigoted as regards 'Mother' (Sri Ma) and considered Her grace and blessings to be of paramount importance. In all these efforts of Swamiji his spiritual daughters (Sister Nivedita and Sister Christine) got the inspiration and unstinted support of Sri Ma Sarada Devi in spreading women education and this was a great strength and inspiration for them.

Swamiji considered more important to set up Mother's Math (Spiritual Institution/nunnery with missionary activities as well) accommodating Her brahmacharin daughters, as an important instrument in nation building ${ }^{55}$. He also wanted such Math to be absolutely independent with full control by women and run only by women ${ }^{43}$. Fulfilling Swamiji's will, though decades later, Mother's Math got set up. They are fully run and administered by women only. There are many such branches in India and abroad spreading the message of spirituality, education and undertaking welfare activity for the people at large . Perhaps in the entire religious history; even considering Budhistic temples and Christian churches (many of whom have some control from the Pope), this is the only and the first organisation which is run independently entirely by women with no other controlling body.

That such philanthropic activities taken up with the spirit of worship, does help in awakening the innate divinity in us, may be gauged from the talk that Swamiji had with Mataji Maharani, the 
Mahratta woman* who founded in Calcutta, the Mahakali Pathshala. Pointing to the little girls whom she taught, she said, "'Swamiji !... these blessed ones I worship, and they will take me to salvation!"58.

[*It is said that she was one of the body guards of Ranee of Jhansi; afterwards she took up monk-hood and coming to Calcutta started this school for little girls, which left its mark at that period.]

It may thus be considered pertinent to elaborate Swamiji's pet phrase 'innate divinity' of human beings with its various connotations and blooming of it.

\section{Divinity, InNATE IN ALL HuMAN BeINGS With its DifFERENT CONNOTATIONS}

Swamiji wrote to his spiritual daughter Sister Nivedita on $7^{\text {th }}$ June, 1896 saying, 'my ideal indeed can be put into few words and that is: to preach into mankind their divinity, and how to make it manifest in every movement of life................Religion in the world have become lifeless mockeries....What the world wants is character." 59 . That is why he wanted man-making education in arousing the innate divinity to all. Thus Swamiji, the world teacher assures to all, saying "All power is within you; ....do not believe that you are weak......you can do anything and everything without even the guidance of one. All power is there. Stand up and express the divinity within you." ${ }^{60}$. He added, "...when a man gets even higher than the plane of the intellect; higher than of mere thought, when he gets to the plane of spirituality and of divine inspiration; he finds there is a state of bliss, compared to which all the pleasures of the senses, or even of the intellect are as nothing. When the moon shines brightly all the stars become dim, 61 .

William Earnest Hocking, a well known and influential philosopher admitted of the profound spell that Swamiji cast upon him, on his call of the 'innate divinity of man' in his Chicago address and writes in his memoirs, ".... I was shocked to think on reading Herbert Spencer etc... ' of man as of the animals- birth, growth, mating, death-and nothing more-finis-!.' ......But even to this day I hear his (Swamiji's) emphatic assertion: ' ......in all men there is that divine essence, undivided and eternal: Reality is One, and that One, which is Brahman, constitutes the central being of each one of us'.....I could feel ....that this man (Swamiji) was speaking from what he knew (realised from his own experience) and not what he had been told ",62. Referring to Swamiji's firm conviction over innate divinity for all, Sister Nivedita writes, "His confidence in that Divine-within-Man, .......was as perfect, and ... as direct, when he talked with the imperialist aristocrat or the American millionaire, as with the exploited and oppressed. But the out-flow of his love and courtesy were always for the simple ${ }^{, 63}$.

That the divinity is innate in all of us, is of course a well known Vedantic concept. "Vedanta claims .. that all ... which we see around us is the outcome of that consciousness of the divine. ....potentially each one of us has that infinite ocean of Existence, Knowledge and Bliss as our birthright, our real nature; and the difference between us is caused by the greater or lesser power to manifest that divine". ${ }^{64}$. Vedanta adds further, "All is the Self or Brahman. ......That which exists is one, sages call it variously.....The more one has been purified and prepared by Yoga and meditation, the clearer are these flashes of realization. This (Truth) was discovered 4000 years ago..." ${ }^{65}$.

But this grand philosophy of human possibility remained confined amongst few individual sages meditating in solitary mountain caves or forests, far from the masses. It was Swamiji who highlighted its profundity, popularized this concept as the property for all with universal adaptability. Making a closer introspection of the different facets of our mind, Swamiji noted that, ".. man enjoys his intellect more than an animal enjoys its senses; and we see that man enjoys spiritual nature even more than his rational nature. So the highest wisdom must be this spiritual knowledge. With this comes bliss". ${ }^{66}$. Elucidating it further Swamiji explained, "The impulsions from the plane of unconsciousness are what we call instinct, and when the same impulsions come from the plane of consciousness we call it spirit. But there is a still higher plane, super-consciousness in man....it is above consciousness and not below it.... It is not instinct. It is inspiration'" ${ }^{67}$. What we call extraordinary, super-conscious inspiration is only the result of a higher development of ordinary consciousness, gained by long and continued efforts. The difference between the ordinary and extraordinary is merely one of the degree in manifestation. Conscious efforts lead the way to superconscious illumination ${ }^{68}$. 
It has been said that for attaining such super conscious inspiration (which is the same as waking up our innate divinity), it would be required to practice with great yearning, at least three of the four existing Yogas; like Karma Yoga, Jnan Yoga, Bhakti Yoga \& Raj Yoga. Swamiji admitting to have unfolded made-easy of each of them for developing their wider applicability, wrote in his inimical language, "I want to give them (all aspirants) dry, hard reason (Janan Yoga), softened in the sweetest syrup of love (Bhakti Yoga) and made spicy with intense work (Karma Yoga) and cooked in the kitchen of Yoga (Raj Yoga), so that even a baby can digest it" ${ }^{69}$. Sister Nivedita rightly spoke of Swamiji that, "... in matters of religion, he (Swamiji) was, without knowing it, a born educator. ${ }^{70}$ ..Where others would talk of ways and means (for yearning on Love of God), he knew how to light a fire. Where others gave directions, he would show the thing itself ${ }^{\prime \prime 11}$. Speaking of Swamiji's ideal on human excellence, Nivedita wrote further "The heart of Buddha and the intellect of Sankaracharya" was always his definition of the highest possibility of humanity" 72 .

Stating another dimension of the 'innate divinity of human' Swamiji writes explaining the philosophical truths of the Vedas (Shruti), "I and the whole universe are one; I and Brahma are one. And this conclusion you will find not only in philosophy, but parts of it through the power of love (Bhakti), ${ }^{, 73}$. Citing on Srimad Bhagvatam Swamiji writes as to how the devotee Gopis meditating deeply over Krishna, completely lost their body-consciousness and each of them identified their own selves with Krishna himself. ${ }^{73}$. In other words it is the same truth stated in Vedas, "Thou art that"; You are God. Elucidating this concept of Love without distinction of Self, Swamiji cites of an ancient Persian poem, which says, "I came to the Beloved and behold the door was closed. I knocked at the door and from inside a voice came, 'Who is there?' I replied, 'I am'. The door did not open. A second time I came and knocked at the door and the same voice asked 'Who is there?' 'I am so and so.' The door did not open. A third time I came and the same voice asked, 'Who is there?' I am thyself my Love', and the door opened ${ }^{73}$. Here Jnan and Bhakti, Philosophy and Love- merge together.

\section{UNIQUENESS IN THE TEACHINGS OF SWAMIJI}

The novelty of Swamiji's faculties lay not only in its uniqueness of the contents of his teachings, but also over the language he used to convey; which were mostly in English. In fact, Swamiji himself was conscious of the enormity of the task and wrote, "It is impossible ..... to translate spiritual ideas and perceptions in the language of reason; and ... saints and all, have declared their inability to make known their spiritual experiences. ....Religion is the science which learns the transcendental in nature through the transcendental in man." ${ }^{74}$.

To what extent Swamiji was successful in this stupendous task can be gauged from an American press report, as also from the response of Harvard University students, who on getting lost in intricacies of philosophical labyrinth considered Swamiji to be 'a teacher par excellence' as recorded by Prof. James ${ }^{75}$. The former commenting in their press release on Swamiji's religious discourses at Detroit in 1894, reported, ".....for nearly two hours Vivekananda wove a metaphysical texture on affairs human and divine, so logical that he made science appear like common sense." ${ }^{, 76}$. As to the latter, Prof James recorded a meaningful and interesting conversation between two students, after they listened to Swamiji's discourse:

" 1 st student: I am not convinced on the profundity of the topic, as we were told of.

$2^{\text {nd }}$ student: Why do you say so.

$1^{\text {st }}$ Student: Because I have understood every word he (Swamiji ) said,,75

These two stories speak volumes of Swamiji's success in his mission -impossible in developing a language of abstruse philosophy and super-conscious spirituality, comprehensible to all. Because of such unique accomplishment on the writings and speeches of Swamiji in English, Sister Nivedita wrote significantly, "Long after the English language has disappeared from India, the gift that has been made through that language, to the world, will remain and bear its fruit in East and West alike, ${ }^{, 77}$.

There are also quite a number of enigmatic puzzles in the life and teachings of Swamiji, which makes him quite original in his approach and at times rather non-conventional, which makes him more lovable and to us. Some of such uniqueness in Swamiji's teachings and life are depicted below. 
- It has been said in Karma Yoga to try to do good to others with complete self-abnegation without expecting anything in return. This is a known age old ethical sermon for cultivating spirituality. But like a pragmatic teacher Swamiji raised the pertinent question, "Why should we do good to the world? Apparently to help the world, but really to help ourselves...... is it not a blasphemy to say that the world need our help? ....We may perfectly be sure that it (world) will go on beautifully without us... Yet we must do good ....it is a privilege to (get the opportunity) to help others. ...it is not the receiver that is blessed, but it is the giver. ....All good acts tend to make us pure and perfect....give up the foolish talk of doing good to the world.....yet we must work and constantly do good, .....because that is the only way we can become perfect', ${ }^{78}$..This novel approach of doing good, is known as Swamiji's famous thesis- Atmano mokshartham jagat hitaya cha (आत्मनो मोक्षार्थ जगद्धिताय च) - doing good to the world for one's own salvation.

- Swamiji said, "External worship is only a symbol of internal worship; but internal worship and purity are the real things" ${ }^{79}$. Citing a simile Swamiji narrates a story of two servants of a rich man. One all the time praising the master and remaining with folded hands showing extreme obedience. And the other, doing all the jobs of the master tirelessly. Naturally the master would be more pleased with the latter. Likewise, who directly serves Shiva, seeing "Shiva in the poor, in the weak, and in the diseased, really worships Shiva; and if he sees Shiva only in the image, his worship is but preliminary" ${ }^{, 79}$. This approach to worship is another uniqueness of Swamiji's teachings, where he considered, 'Service to Man (considering to be the symbol of divinity) with self-abnegation and in the spirit of worshipping, is always higher in the attainment of spirituality, than the ritualistic worship with prayers etc, which he called to be of the external category. He also wrote in another context, more or less expressing the same spirit, "If a man retires from the world and worship God, he must not think that those who live in the world and work for the good of the world are not worshipping God...... Each is great in his own place" ${ }^{, 80}$.

- Another important faculty on Swamiji's claim in resolving philosophical riddles has been recorded by Nivedita. She wrote, "Hitherto, the three philosophic systems of - Unism, Dualism, and Modified Unism, or Advaita, Dvaita, and Visishtadvaita - had been regarded as offering to the soul, three different ideals of liberation. No attempt had ever before been made to reconcile these schools. On reaching Madras, however, in 1897, Vivekananda boldly claimed that even the utmost realisations of Dualism and Modified Unism, were but stages on the way to Unism itself; and the final bliss, for all alike, was the mergence in One without a second.......(on the question) . if this was the truth, (why) it had never before been mentioned by any of the Masters.... the great gathering was startled, on this occasion, to hear the reply "Because I was born for this, and it was left for me to do!"81

- Swamiji laid great emphasis in following strict moral virtues, and in education system he wanted the practice of Brahmacharya to the aspiring students forming the foundation of imparting real education. But, he was against making moral legislation for its implementation, devoid of rational approach. Revolting against such rule-book custom abidance to make a nation moral, not paying heed to rationality and arousing of individual will power, Swamiji said bitterly in a talk at prairie Club (USA), “ ....his (Indian) people were the victim of too much legislation. ...the people have been dwarfed intellectually by this weight of moral legislation. For ages it has crushed them down till they have no moral guide but law. ..They have no choice between right and wrong. They are mere automatons" ${ }^{\prime \prime}$. Swamiji wanted not to make man a machine to make them moral, but developing will power in them with conscious effort of practicing morality, not just rule book followers. In fact, though Swamiji himself formulated certain rules to maintain discipline in the Ramakrishna Math \& mission that he established, but simultaneously he cautioned, "Frame laws, but frame them in such a fashion that when people are ready to do without them, they can burst them asunder. Our originality lies in combining perfect freedom with perfect authority" ${ }^{, 83}$.This was the novelty of Swamiji. 
- Echoing the spirit of the great Raj Yoga teacher Patanjali who said, " who is able to reject all the powers ( attained from practice of Raj Yoga), comes the cloud of virtue. He, alone attains the very highest" ${ }^{\prime \prime 4}$; Swamiji also decried against show off of miracles. To the Detroit audience who wanted to show some miracles, he rebuked saying, "Ye would not believe Moses and prophets, neither ye believe though one arose from the dead. It is only the ignorant who expect or seek for the miraculous" ${ }^{84}$ An interesting incident may be worth citing here. The widow daughter-in-law of Mr John B Lyons, Swamiji's host at Chicago, after practicing Raj-Yoga for some period, acquired a strange power. If she held even a torn piece of paper of anybody, she could form vivid impression both physically and mentally of the writer concerned. On asking Swamiji of this strange power acquired, Swamiji advised her to use this gift only for the good of mankind, not otherwise. ${ }^{85}$

- Sister Nivedita also wrote of an important aspect on Swamiji's life which escapes attention of not-so-careful readers of Swamiji's life. Sister Nivedita wrote, "He (Swamiji) never appeared to be practising austerity, but his whole life was a concentration so profound that to anyone else, it would have been the most terrible asceticism" ${ }^{\prime \prime}$.

- Though Swamiji was an out and out religious teacher advocating renunciation and asceticism for attainment of spirituality, but he was pragmatic enough in not denying the weightage held on the material prosperity over many. Hence, he assured proclaiming, ".A God who could not in this life give a crust of bread, was not to be trusted in the next for the kingdom of heaven!" ${ }^{87}$. He also felt that only by the spread of knowledge could the country as a whole be kept steadfast in its reverence for the greatness of its own inherited culture, intellectual and religious. ${ }^{88}$.

- Swamiji, whilst speaking with his fellow monks hours over the supreme charm that Sree Ramakrishna, their Guru cast over them, ultimately said in unison that the one word which can portray Him is L-O-V-E. He was love incarnate. (Sa Isha Prema Swarupah-meaning, Love is God, God is Love). In fact, the same portrayal is applicable for Swamiji as well. On getting the telegram about the demise of Swamiji's disciple cum steno Goodwin, Swamiji got so much upset he murmured within himself, "Now I realise how tormenting is the death news of the son to a father!" ${ }^{\prime 9}$. On another occasion, on seeing Swamiji shedding tears at the death news of Sree Ramakrishna's disciple Balaram Bose, Pramada Das Mitra, a noble man of Varanasi \& Sanskrit scholar, reproached Swamiji saying that being a monk he should not be so much grief-stricken. Swamiji replied that he does not believe in such monk-hood which suppresses the response of the heart ${ }^{90}$. In fact, Swamiji preferred responding to the call of the heart than choose the logic of head.

- It is said that while moving as a wondering monk, Swamiji suddenly declared that he would move alone deeper inside Himalayas, and immediately left the place at Hrishikesh in a huff, where Swami Sadananda, his disciple was preparing food for Swamiji. Being dumbfounded and saddened Sadananda sat still virtually weeping being deprived of the company of his Guru. After 3-4 hours Swamiji returned back, being worried like a mother for the helplessness of saddened Sadananda, left alone at Hrishikesh. Happily taking food prepared by Sadananda they then set out together deeper in the Himalayas. It was like a mother retuning back from her job unfinished, to take the helpless weeping child in her lap. In fact, Swamiji had virtually to carry Sadananda in his lap like a mother, since Sadananda fell seriously sick in passing through the difficult terrains of the Himalalyas. Many a times in crossing the slippery water logged narrow hilly paths of Himalayas Swamiji risked his own life to save Sadananda ${ }^{91}$.

- More or less same love of Swamiji was bestowed to all his disciples, fellow monks, friends and to all those whosoever came across him. No wonder, when Martha Brown Fincke (also joined Swamiji's Raj Yoga classes) while narrating decades later of an incident that she came across and felt that Swamiji personified Power; the monks of Belur Math told that Swamiji was rather personified Love ${ }^{92}$. They all admitted that it was rather the tender motherly love of Swamiji that won them over and made him more beloved to them, than even his 
overpowering dazzling personality with the wisdom of a sage. In fact, such love stems from his insight identifying Self in all and divinity to all.

\section{CONCLuSion}

Sister. Nivedita wrote while speaking of Swamiji as the world teacher, "I see in him (Swamiji) the heir to the spiritual discoveries and religious struggles of innumerable teachers and saints in the past of India and the world, and at the same time the pioneer and prophet of a new and future order of development'. This gives the exact depiction of the challenges and successes of Swamiji as the world teacher for the new order.

In fact, it was his Guru, Sree Ramakrishna, who giving Swamiji his empowerment, wrote in his death bed in Bengali, "Naren Sikse Debe, Jore Hank Debe"; which means "It is Naren (Swamiji) who will teach the world. He will give a clarion call loud and clear to all in the globe". Swamiji did exactly that over which his Guru, the prophet of the nuclear age of the global village, authorized him to do.

Sree Ramakrishna's last line in that authorization letter of Swamiji, seem to be apparently out of context, but very much significant and relevant. This last line that Sree Ramakrishna wrote in Bengali was: "Sree Radha Premamoyee"'. Literally it means, Sree Radha, the symbol of 'divine love' is Love all over. It seems Sree Ramakrishna wanted Swamiji to form the foundation of his teaching over this 'divine love', which in itself can also be said to constitute the motive power for spreading his teachings. The same ideal is expressed in Swamiji's letter to Nivedita, where he wrote, "The world is in need of those whose life is one burning love - self-less. That love will make every word tell like a thunder-bolt. Awake, awake, great souls! The world is burning in misery. Can you sleep?" ${ }^{93}$.

This wakeup call through Nivedita, is a message of Swamiji for all to awake the divinity that dwells within all of us

\section{ACKNOWLEDGEMENT}

The author acknowledges his thanks to Dr Jayasis Bandyopadhyay, FRCOpth (Lond.), Consultant of James Cook University Hospital, UK, for overseeing the article with valuable suggestions.

\section{REFERENCES}

[1] In.<http://www.perkins.org/history/people/annesullivan?gclid=CP_BrqaHjNECFdgSaAodTK0MBw > [24th Dec. 2016].

[2] In http://joanofmark.blogspot.in/2013/05/helen-keller-with-rabindranath-tagore-c.html [2nd Jan. 2017].

[3] In. <http://www.space.com/52-the-expading-universe-from-the-big-bang-to-today.html>[22. 12. 2015]. n

[4] The Complete Works of Swami Vivekananda (1989), Mayavati Memorial Edition, 1989, Advaita Ashram, Calcutta.vol.3.p.93.

[5] Ibid. vol.1.pp.225-226.

[6] Ibid.vol.1.p.158.

[7] In.<http://www.space.com/18811-multiple-universe-5-theories.html> [30.1.17]

[8] The Complete Works of Swami Vivekananda (1989), Mayavati Memorial Edition, 1989, Advaita Ashram, Calcutta.vol.1.p.148-149.

[9] Ibid. vol.1. p.159.

[10] Ibid. vol.1.p.147.

[11] Ibid. vol.1.p.151.

[12] Ibid. vol.2.pp.10-11.

[13] Ibid. vol.2.p.16.

[14] Ibid. vol.2.p.17

[15] Ibid. vol.2.pp.13-14.

[16] Marie Louis Burke (1994). Swami Vivakananda in the West, New Discoveries. The Prophetic Mission, Advaita Ashram, Kolkata, Part-2. pp.53-54.

[17] Ibid. Part-1.p.81.

[18] The Complete Works of Swami Vivekananda (1989), Mayavati Memorial Edition, 1989, Advaita Ashram, Calcutta. vol. 2. p. 440. 
[19] Ibid. vol.1.p.183

[20] Ibid. vol.1.pp.509-510

[21] Ibid. vol.8.p.267.

[22] Letters of Swami Vivekananda (2012), Advaita Ashram, Kolkata, dated 24th April, 1897, pp. 327-331.

[23] The Complete Works of Swami Vivekananda (1989), Mayavati Memorial Edition, 1989, Advaita Ashram, Calcutta. vol. 8. pp.88-89.

[24] In. <http://en.wikipedia.org/wiki/Literacy_in_India> [7th March, 2017]

[25] The Complete Works of Swami Vivekananda (1989), Mayavati Memorial Edition, 1989, Advaita Ashram, Calcutta.vol. 8. pp. 307-308.

[26] Letters of Swami Vivekananda (2012), Advaita Ashram, Kolkata, dated 19th March, 1894, pp.78-83

[27] Marie Louis Burke (1994). Swami Vivakananda in the West, New Discoveries. The Prophetic Mission, Advaita Ashram, Kolkata, Part-1. pp.260-261.

[28] Ibid.Part-1.P.430.

[29] Ibid. Part-1.p.357.

[30] c vol.7.pp 507-508.

[31] Ibid. vol.7.pp. 147-148.

[32] Ibid. vol.7.p.183.

[33] Marie Louis Burke (1994). Swami Vivakananda in the West, New Discoveries. The Prophetic Mission, Advaita Ashram, Kolkata,Part-1.p.125.

[34] The Complete Works of Swami Vivekananda (1989), Mayavati Memorial Edition, 1989, Advaita Ashram, Calcutta vol.8.p.85.

[35] In. <https://en.wikipedia.org/wiki/M._S._Swaminathan> [11th April, 2017].

[36] The Complete Works of Swami Vivekananda (1989), Mayavati Memorial Edition, 1989, Advaita Ashram, Calcutta. vol.5.pp.380-381.

[37] Letters of Swami Vivekananda (2012), Advaita Ashram, Kolkata, dated 19th March, 1894,dated 11th July, 1897. pp.353-355.

[38] The Complete Works of Swami Vivekananda, Mayavati Memorial Edition, 2004, Advaita Ashram, Calcutta, vol.9. pp. 545-547.

[39] The Complete Works of Swami Vivekananda (1989), Mayavati Memorial Edition, 1989, Advaita Ashram, Calcutta. vol.5. pp.364-369.

[40] Ibid. vol.3.pp.298-299.

[41] The Master as I Saw Him. Being pages from the life of Swami Vivekananda by His Disciple Nivedita of Ramakrishna -Vivekananda, Longmans, Green and Company, 1910.p.149.

[42] The Complete Works of Swami Vivekananda (1989), Mayavati Memorial Edition, 1989, Advaita Ashram, Calcutta.vol.5.pp.364-369.

[43] The Complete Works of Swami Vivekananda, Mayavati Memorial Edition, 2004, Advaita Ashram, Calcutta. vol.9. p.535.

[44] The Complete Works of Swami Vivekananda (1989), Mayavati Memorial Edition, 1989, Advaita Ashram, Calcutta, vol.7.p.220.

[45] Ibid. vol.8.p.91.

[46] Ibid.vol.7.pp.214-215.

[47] Ibid.vol.2.p.100.

[48] Letters of Swami Vivekananda (2012), Advaita Ashram, Kolkata, dated 23rd Dec. 1895, p.273.

[49] The Complete Works of Swami Vivekananda (1989), Mayavati Memorial Edition, 1989, Advaita Ashram, Calcutta. vol.5. p.24.

[50] Marie Louis Burke (1994). Swami Vivakananda in the West, New Discoveries. The Prophetic Mission, Advaita Ashram, Kolkata,Part-1, p.101.

[51] The Complete Works of Swami Vivekananda (1989), Mayavati Memorial Edition, 1989, Advaita Ashram, Calcutta. vol.5. p.231.

[52] Marie Louis Burke (1994). Swami Vivakananda in the West, New Discoveries. The Prophetic Mission, Advaita Ashram, Kolkata,Part-1, p.98

[53] The Complete Works of Swami Vivekananda (1989), Mayavati Memorial Edition, 1989, Advaita Ashram, Calcutta. vol.5.p.342. 
[54] Letters of Swami Vivekananda (2012), Advaita Ashram, Kolkata, dated 29th July, 1897.pp. $362-364$.

[55] In. <https://en.wikipedia.org/wiki/Sister_Christine> [19.3.2017]

[56] The Master as I Saw Him. Being pages from the life of Swami Vivekananda by His Disciple Nivedita of Ramakrishna -Vivekananda, Longmans, Green and Company, 1910. p.148.

[57] Letters of Swami Vivekananda (2012), Advaita Ashram, Kolkata, dated 1894. pp.179-183.

[58] The Master as I Saw Him. Being pages from the life of Swami Vivekananda by His Disciple Nivedita of Ramakrishna -Vivekananda, Longmans, Green and Company, 1910. p.71.

[59] In <http://srisaradamath.org/bharatiprana.php> [12th April, 2017]

[60] The Master as I Saw Him. Being pages from the life of Swami Vivekananda by His Disciple Nivedita of Ramakrishna -Vivekananda, Longmans, Green and Company, 1910. p.140.

[61] Letters of Swami Vivekananda (2012), Advaita Ashram, Kolkata, dated 7th June, 1896. pp. $294-295$.

[62] The Complete Works of Swami Vivekananda (1989), Mayavati Memorial Edition, 1989, Advaita Ashram, Calcutta, vol.3.p.284..

[63] Ibid. vol.3.p.72.

[64] Marie Louis Burke (1994). Swami Vivakananda in the West, New Discoveries. The Prophetic Mission, Advaita Ashram, Kolkata,Part-1, pp.117-118.

[65] The Master as I Saw Him. Being pages from the life of Swami Vivekananda by His Disciple Nivedita of Ramakrishna -Vivekananda, Longmans, Green and Company, 1910. p.106..

[66] The Complete Works of Swami Vivekananda (1989), Mayavati Memorial Edition, 1989, Advaita Ashram, Calcutta. vol.1.p.388.

[67] Ibid. vol.8.pp.12-13.

[68] Ibid. vol.3.p.4.

[69] Ibid. vol.4.p.212

[70] Ibid.vol.4.p.436.

[71] Letters of Swami Vivekananda (2012), Advaita Ashram, Kolkata, dated 13th Feb. 1896. p. 283.

[72] The Master as I Saw Him. Being pages from the life of Swami Vivekananda by His Disciple Nivedita of Ramakrishna -Vivekananda, Longmans, Green and Company, 1910. p. 80.

[73] Ibid. p.50.

[74] Ibid.p.127.

[75] The Complete Works of Swami Vivekananda (1989), Mayavati Memorial Edition, 1989, Advaita Ashram, Calcutta. vol.3.p. 282.

[76] Ibid.vol.8.p.20-21.

[77] Marie Louis Burke (1994). Swami Vivekananda in the West, New Discoveries, The World Teacher, Part2, pp87-88.

[78] Marie Louis Burke (1994). Swami Vivekananda in the West. New Discoveries. Part-1. p. 334.

[79] The Complete Works of Swami Vivekananda (1989), Mayavati Memorial Edition, 1989, Advaita Ashram, Calcutta. vol.1.p.ix .

[80] Ibid. vol.1.pp.75-79.

[81] Ibid.vol.3.pp.141-143.

[82] Ibid.vol.1.p.47.

[83] The Master as I Saw Him. Being pages from the life of Swami Vivekananda by His Disciple Nivedita of Ramakrishna -Vivekananda, Longmans, Green and Company, 1910. p.114.

[84] Marie Louis Burke (1994). Swami Vivekananda in the West. New Discoveries. Part-1. p. 334.

[85] The Master as I Saw Him. Being pages from the life of Swami Vivekananda by His Disciple Nivedita of Ramakrishna -Vivekananda, Longmans, Green and Company, 1910. p.148.

[86] Ibid.p.167.

[87] Marie Louis Burke (1994). Swami Vivekananda in the West. New Discoveries. Part-1. p. 329.

[88] Ibid. p.156.

[89] The Master as I Saw Him. Being pages from the life of Swami Vivekananda by His Disciple Nivedita of Ramakrishna -Vivekananda, Longmans, Green and Company, 1910. p.179.

[90] Ibid.p.141.

[91] Swami Abjajananda (1983) Swamijir Podaprante, Udbodhan Karyalaya, 1983, p.242 (In Bengali). 
[92] Swami Gambhirananda (1985).Yuganayak- Part 1. Udbodhan Karylaya, 1985. p.182 (In Bengali).

[93] Swami Abjajananda (1983) Swamijir Podaprante, Udbodhan Karyalaya, 1983, p.228-229 (In Bengali).

[94] Marie Louis Burke (1994). Swami Vivekananda in the West. New Discoveries. Part-2. pp. 28-30.

[95] The Master as I Saw Him. Being pages from the life of Swami Vivekananda by His Disciple Nivedita of Ramakrishna -Vivekananda, Longmans, Green and Company, 1910. p.49.

\section{AUTHOR'S BIOGRAPHY}

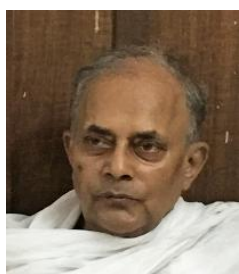

Dr SudhishChanndra Banerjee, has taken up studies on RamakrishnaVivekananda literature for the last few decades, post retirement as Deputy Director from a CSIR institute at Dhanbad, and is publishing his findings on the same in various English and Bengali Journals, as a free lance writer intending to share his thoughts with others.

During his working period at the CSIR Institute, the author, a PhD in Chemistry from the Calcutta University, published two reference books on his specialization, Mine Fires, published by AA Balkema, the Netherlands, and Oxford IBH Pub. Co. India, simultaneously. He had around 50 research papers published in various national and international Journals of repute and also 2 patents on his specialization.

Citation: Sudhish Chandra Banerjee. "Swami Vivekananda -The Teacher." International Journal of Humanities Social Sciences and Education (IJHSSE), vol 5, no. 1, 2018, pp. 1-15. doi: http://dx.doi.org/10. 20 431/2349-0381.0504001.

Copyright: (C) 2018 Authors. This is an open-access article distributed under the terms of the Creative Commons Attribution License, which permits unrestricted use, distribution, and reproduction in any medium, provided the original author and source are credited. 